\title{
THE MEANING OF FRACTURES: ORTHOPAEDICS AND THE REFORM OF BRITISH HOSPITALS IN THE INTER-WAR PERIOD
}

by

\section{ROGER COOTER*}

It is not immediately obvious that any history of the treatment of fractures could significantly illuminate the development of twentieth-century medicine. Could such a history be much more than a chronicle of therapeutic traditions, technical advances, and forgotten pioneers? That would indeed be desolately dry-boned, even by the standards of "internal" medical historiography."

But any such assumptions would be wrong. Although the treatment of fractures was never quite the social concern that tuberculosis and maternity were, it was a highly significant issue in the politics of medicine and hospitals in inter-war Britain. In the 1930s especially, the issue was to link the leaders of the medical profession with leaders of industry, trade unions, and local and national government. Increasingly, it drew the attention of the British Medical Association (BMA), the Trades Union Congress (TUC) and Labour Party, the Federation of British Industry, the London County Council (LCC), and the Ministries of Health, Labour, and Pensions, along with many other special-interest groups.

For the fracture issue, then, no less than for tuberculosis and maternity, the historian must ask how and why its importance arose when it did. To attempt an answer is necessarily to engage with the economic, social, and political history of the inter-war decades; after all, like tuberculosis, fractures had long been a common source of suffering and death and of severe and usually prolonged socio-economic deprivation. Moreover, some of the same urgent arguments for remedial action that were to be deployed in the 1920 s and 1930s can be found from the middle of the nineteenth century. ${ }^{2}$

This paper examines the issue from the perspective of the professional interests and aspirations of orthopaedic surgeons in the inter-war period. In large part, it was out of the orthopaedists' ambition to gain control over fracture treatment, and so enlarge their professional space, that the issue came to acquire its importance in Britain. ${ }^{3}$ But

\footnotetext{
* Roger Cooter, MA, PhD., Manchester Wellcome Unit for the History of Medicine, c/o Department of Science and Technology Policy, University of Manchester, M13 9PL.

${ }^{1}$ See, for example, E. M. Bick, 'Fractures', in his Source book of orthopaedic surgery, 2nd ed., Baltimore, Md., Williams \& Wilkins, 1948, ch. 10.

${ }^{2}$ See, for example, John Roberton, 'On the need of additional as well as improved hospital accommodation for surgical patients in manufacturing and mining districts, but especially in Manchester', Trans. Manchester Stat. Soc., 1860 (reprinted pamphlet).

${ }^{3}$ In the United States, orthopaedicsurgeonssecured placesin hospitalsand university medicalschoolsmuch earlier than in Britain. Hence fractures never acquired the same professional significance. As early as 1907 , general surgeons at the Rochester General Hospital agreed to have all fractures assigned to the orthopaedic service; hospitals in Boston and elsewhere followed suit after the 1914-18 war. (See J. Bone Jt Surg., 1955,
} 


\section{The meaning of fractures}

this is not the whole of the story, nor the main reason for its historical importance. The fracture issue was integral to the shift in this century to a focus on accidents and trauma-a shift of focus with wide but understudied implications. ${ }^{4}$ Although the First World War "cast a halo" on trauma and brought the concern with it on to a par with disease entities, the halo might well have slipped had it not been for the proponents of fracture services during the interwar period. ${ }^{5}$ But because accidents and trauma cut across the "organ geography" of medical and surgical specialties, the attempt to shift the focus was to raise serious problems of conceptualization as well as of hospital organization. As we shall see, it was in relation to these problems especially that the efficient treatment of fractures became central to the politics of British hospital reform before the Second World War.

\section{WAR GAINS AND POST-WAR LOSSES}

The common belief that modern orthopaedics derives in large part from traditional bone-setting appears to legitimate orthopaedic surgeons as the rightful menders of broken bones. ${ }^{6}$ But, in fact, it was only through the First World War that orthopaedists as a professional body brought the treatment of fractures within the scope of their specialism. ${ }^{7}$ (Indeed, it was largely as a result of the wartime work with fractures that professional association re-emerged and was made permanent.) Hitherto, orthopaedics had been almost wholly concerned with the correction of chronic deformities, especially among children. Although from the 1890s the therapeutic techniques of fracture treatment were increasingly the subject of medical attention (leading to a BMA report in 1912), ${ }^{8}$ the practice of fracture treatment had

37A: 383.) Unlike in Britain, however, where the majority of fractures-as much as ninety-five per cent of compound fractures - continued to be treated by general practitioners (J. Amer. Med Ass., 30 November 1940: 1855).

${ }^{4}$ For some of the conceptualimplications, see Karl Figlio: 'What is an accident?', in Paul Weindling(editor), The social history of occupational health, London, Croom Helm, 1985, pp. 180-206; and idem, 'How does illness mediate social relations? Workmen's compensation and medico-legal practices, 1890-1940', in P. Wright and A. Treacher (editors), The problem of medical knowledge, Edinburgh University Press, 1982, pp. 174-224.

${ }^{5}$ The description of the war as "casting a halo on trauma" was given by Sir Harry Platt in an interview with the author, 7 November 1984. For background on trauma, see C. T. Thompson, 'Trauma center development', in J. S. Najarian and J. P. Delany (editors), Emergency surgery: trauma, shock, burns, Chicago, Year Book Medical Publishers, 1982, pp. 15-20. The existing Committee on Trauma of the American College of Surgeons began life in 1922 as the Committee on Fractures; the Société Internationale de Chirurgie Orthopédique (established in 1929) added "et de Traumatologie" to its title in 1936. See Franklin Martin, Fifty years of medicine and surgery, an autobiographical sketch, Chicago, Surgical Publishing Co., 1934, pp. 349-350; and Sir Harry Platt, 'Orthopaedics in continental Europe, 1900-1950', in his Selected papers, Edinburgh, E. \& S. Livingstone, 1963, pp. 65-88, at p. 66.

${ }^{6}$ See, for example, George Rosen, The specialization of medicine, New York, Froben Press, 1944, pp. 10-11; Arthur Keith, Menders of the maimed, London, Frowde, 1919; and cf. Roger Cooter, 'Bones of contention? Orthodox medicine and the mystery of the bone-setter's craft', in W. F. Bynum and R. S. Porter (editors), Medical fringe and medical orthodoxy, London, Croom Helm, 1986, pp. 158-173.

${ }^{7}$ Robert Jones, who as early as 1896 had suggested to the short-lived British Orthopaedic Society (est. 1894) that they widen their domain to include fractures (Trans. B.O.S., 1896, 1: 33), defined the specialism in 1917 as "the treatment by manipulation, by operation, and by re-education, of disabilities of the locomotor system, whether arising from disease or injury". 'Orthopaedic surgery in its relation to the war', Recalled to life, 1917, 1: 50-59, at p. 51.

8 'British Medical Association Report of the Committee on Treatment of Simple Fractures', Br. med. J., 1912, ii: 1505-1541. The report was promoted by attention to the open-plating techniques of Arbuthnot 


\section{Roger Cooter}

remained largely in the hands of general practitioners and hospital general surgeons. The only exception was the work of Robert Jones in Liverpool, and that was conducted in a private clinic (mostly for the treatment of industrial injuries) established by his uncle, the general practitioner, Hugh Owen Thomas. ${ }^{9}$

How orthopaedists secured the treatment of fractures during the war through the political and organizational genius of Robert Jones does not concern us here; ${ }^{10}$ more important to note is that, after the war, orthopaedists were unable to carry over into civilian hospital practice their military control of fractures, largely because of opposition from old-guard general surgeons (especially in London). To these "reactionaries", as Jones and his colleagues referred to them, orthopaedics appeared the most conspicuous of several insurgent specialisms threatening completely to outmode general surgery. By 1918 , not only had vast portions of general surgery been hived off into seventeen specially designated military orthopaedic centres (commanding over 25,000 beds), ${ }^{11}$ and not only had some two dozen ambitious disciples of Jones come together (in February 1918) to form the British Orthopaedic Association (BOA); but also the specialism had acquired an exhalted public image as a result of the rehabilitation of disabled soldiers. Jones's wartime "headquarters" - the Shepherd's Bush Military Orthopaedic Hospital in London-had become a national symbol of the success of wartime medicine.

The "old guard" were also well aware that orthopaedics in Jones's hands represented certain anti-traditional and distinctly unpleasant American tendencies. ${ }^{12}$ Before the war, Jones, along with other outstanding British surgeons, had been a member of Sir Berkeley Moynihan's Provincial Surgeons' Association, a visibly modernist group deeply influenced by American surgery and the "scientific" hospital organization that had emerged in America during the Progressive Era. ${ }^{13}$ It was those within or identifying with

Lane at Guy's Hospital, and by attention to the radically conservative fracture treatment of J. Lucas-Championniere in France. The report prompted Robert Jones, 'On the present position of treatment of fractures', ibid., 1912, ii: 1589-1594; and idem., 'An orthopaedic view of the treatment of fractures', Amer. J. Orthop. Surg., 1913, 11: repr. in E. M. Bick (editor), Classics in orthopaedics, Philadelphia, J. P. Lippincott, 1976, pp. 348-360 - the first systematic account of the treatment of fractures to bear the word "orthopaedics" in its title.

${ }^{9}$ See Frederick Watson, The life of Sir Robert Jones, London, Hodder \& Stoughton, 1934; and David Le Vay, The life of Hugh Owen Thomas, Edinburgh, E. \& S. Livingstone, 1956.

10 For fuller discussion of the orthopaedists' involvement with the war, as well as their involvement with crippled children, industry, and organized labour and other areas referred to here only in passing, see my forthcoming book on the social history of orthopaedics.

${ }^{11}$ According to the Army Council Instruction (A.C. I 72, 1916) devised by Jones, the following were to be sent to the military orthopaedic hospitals: (1) cases of plastic surgery of face, neck and jaw; (2) any case of deformity or disability of the feet; (3) any case of mal-united fracture or un-united fracture; (4) any case of fracture of the femur; (5) any case of derangement or disability of joints; (6) any case requiring a special surgical appliance; (7) any case of nerve lesion requiring treatment. Cited in the report of the Orthopaedic Committee of the Royal College of Surgeons, 4 July 1918, in MS Committee for Temporary Purposes, vol.. 6, 1907-22, pp. 312-315, Royal College of Surgeons.

12 The significance of orthopaedics for the old guard in Britain was similar to the significance of gynaecology for American general surgeons during the Progressive Era. This comparison was explicitly used to promote orthopaedic specialization by a disciple of Jones, W. Rowley Bristow, in 'Discussion on the treatment of fractures', Br. med J., 1925, ii: 317-331, at p. 331. On the old guard's distaste for things American in medicine, see Charles Macalister, The origin and history of the Liverpool Royal Hospital, with personal reminiscences, Liverpool, W. B. Jones, 1936, p. 57ff.

${ }^{13}$ See Platt, 'Moynihan; the education and training of the surgeon', in his Selected papers, op. cit., note 5 above, pp. 159-169; and idem., 'The foundation of the Association of Surgeons of Great Britain and Ireland', Br. J. Surg., 1982, 69: 561-563. 


\section{The meaning of fractures}

this reformist élite, most of whom (including Jones) had close personal and professional links with the Mayo brothers, who established the British Journal of Surgery in $1913,{ }^{14}$ and who, through the contingencies of the war and largely at the expense of the old-guard London surgeons, secured for themselves positions of power in the Army Medical Advisory Council under the reform-minded Director-General of the Army Medical Services, Sir Alfred Keogh. Several of the more politically active in this group, among them Harold Stiles of Edinburgh, Henry Gray of London, John Lynn-Thomas of Cardiff, Ernest Hey Groves of Bristol, William de Courcy Wheeler of Dublin, and, latterly, Harry Platt of Manchester, came to be directly involved in the wartime organization of orthopaedics, as did several leading American orthopaedists. It is not, therefore, difficult to credit the rumour that when Keogh appointed Jones Director of Military Orthopaedics in 1916, senior members of the Royal College of Surgeons petitioned their president to have the appointment rescinded. It is a fact, at any rate, that immediately after the war a committee of the council of the College sought to circumscribe orthopaedics, regarding with "mistrust and disapprobation the movement in progress to remove the treatment of conditions always properly regarded as the main portion of the general surgeon's work from his hands, and place it in those of 'Orthopaedic specialists'," 15

Thus, in large part because of their professional achievements under Jones during the war, orthopaedists found their post-war path obstructed. Moreover, while the teaching hospital establishment had no intention of "letting in" orthopaedists, the military orthopaedics centres were returned to their pre-war uses. The Shepherd's Bush Hospital, for example, despite efforts by Jones to turn it into a postgraduate orthopaedic teaching centre, was repossessed by the Hammersmith Guardians in 1924 and restored as a Poor House and Infirmary. Quite literally in many cases, the "modernists" in orthopaedics were forced out into the country, there to be involved with open-air hospitals for crippled children, dealing mainly with cases of rickets and tuberculosis of the bones and joints. A decade after the war, no less than fifty-four of the by then ninety-four senior members of the BOA had resident or consultancy positions at these and other children's hospitals (sixteen of them holding more than one such appointment), as did forty-two of the sixty-seven junior or "associate" members. Although this area of their work cannot be gone into here, it is worth pointing out that the "national scheme" for the orthopaedic care of crippled children that Jones and his colleagues devised in 1919, and to which they were more or less compelled to devote their post-war energies, had largely met with success by the late 1920 s, when some two dozen or so pukka orthopaedic hospitals had been brought into

\footnotetext{
${ }^{14}$ See Donald Bateman, Berkeley Moynihan, surgeon, London, Macmillan, 1940; Martin, op. cit., note 5 above; Helen B. Clapesattle, The Mayo brothers, Boston, Houghton Mifflin, 1962; and William Mayo, 'Present-day surgery in England and Scotland, from notes made on a recent short visit', reprint from $J$. Minnesota State Med. Assn. and Northwestern Lancet, 1 December 1907.

${ }_{15}$ Report of the RCS Orthopaedic Committee, 4 July 1918, op. cit., note 11 above,p. 313. On the rumour, see Platt, 'Moynihan', op. cit., note 11 above, p. 163; and T. B. Layton, Sir William Arbuthnot Lane, an enquiry into the mind and influence of a surgeon, Edinburgh, E. \& S. Livingstone, 1956, p. 109. For the reaction of general surgeons in America to the wartime gains of orthopaedics, see G. Gritzer and A. Arluke, The making of rehabilitation; a political economy of medical specialization, 1890-1980, Berkeley, University of California Press, 1985, p. 44ff.
} 


\section{Roger Cooter}

existence along with countless orthopaedic clinics. ${ }^{16}$ For the most part, it was in the wake of this accomplishment, made outside the major centres of British medicine, that orthopaedists came to concentrate on the issue of fractures-the planning, organization, and rhetoric for which to some extent overlapped.

\section{THE PILOT FRACTURE CLINIC}

To the general picture of the failure of orthopaedic surgeons to secure the control of fracture treatment in the immediate post-war period there were, however, two notable exceptions - the work of Meurice Sinclair, conducted at the St James Poor Law Hospital, Balham, London, and that of Harry Platt at the Ancoats Hospital, Manchester. Sinclair's work derived directly from his pre-eminent wartime handling of fractures at a base hospital in France, and it was to have considerable bearing on LCC thinking on fracture services in the 1930s. But it was little noticed before then, neither was Sinclair a member of the BOA until 1935, though he regarded himself as professionally indebted to Jones. ${ }^{17}$ Platt, by contrast, was a founder member of the BOA, and his work at Ancoats was intended from the start as a demonstration of orthopaedic specialization. In this, as in much of his other work, Platt was greatly influenced both by Jones and by American models.

After graduating in medicine at Manchester in 1911, Platt had gone to London to "round off' his education by gaining experience at the specialist hospitals of St Peter's (genito-urinary), St. Mark's (colo-rectal), and the Royal National Orthopaedic. ${ }^{18}$ Platt was not at this time seeking to become a specialist, but while he was at the RNOH in 1913 , he was invited by the head of the Orthopaedic Service of the Massachusetts General Hospital to further his training in Boston. The experience was decisive; the MGH, with the Boston Children's Hospital and Harvard Medical School, was then the world's leading centre for orthopaedics, embracing all that was most advanced in American medicine. Platt's Orthopaedic surgery in Boston, written just before he returned to Manchester in April 1914 to secure the appointment of honorary

${ }^{16}$ See Jones and G. R. Girdlestone,'The cure of crippled children. Proposed national scheme', Br. med. J., 1919, ii: 457-460. On the orthopaedic hospitals, see Central Council for the Care of Cripples, Directory for 1935, London, 1935.

${ }_{17}$ In 1937, the then twenty-bed orthopaedic unit at St James received no fewer than 735 in-patients for fracture treatment. Sinclair was the consulting orthopaedic specialist and William Gissane (on whom see below) was the senior assistant medical officer. According to Gissane, it was he who, in 1934, "introduced modern methods of fracture treatment to this hospital", but this would seem to have consisted mostly of streamlining what Sinclair had already established. See the report on 'Orthopaedic after care, 1932-47', Greater London Record Office [hereinafter GLRO]: PH/HOSP/1/66; see also, 'BMA Report of Committee on Fractures', Br. med. J., suppl., 16 February 1935, 53-62 at p. 57. On Sinclair's 92-bed segregated fracture service at No. 8 Stationary Hospital, Wimereux, France, see Robert Jones, 'Introduction' to Sinclair, Fractures, London, Constable, 1931, pp. xxxiii-iv; and Harvey Cushing, From a surgeon's journal, 1915-1918, London, Constable, 1936, entry for 4 June 1917, p. 113.

${ }_{18}$ Biographical information on Platt comes from the appreciations by $\mathbf{H}$. Osmond-Clarke and others in Platt's birthday volume of the J. Bone Jt Surg., 1966, 48B: 613-622; various incidental lectures and addresses by Platt (mostly unpublished); and several interviews conducted by myself and others between 1974 and 1985. See also the introduction to Stella Butler, 'A handlist for the papers of Sir Harry Platt', typescript, 1984. On the RNOH see J. A. Cholmeley, The history of the Royal National Orthopaedic Hospital, London, Chapman \& Hall, 1985; on St Peter's see A. Clifford Morson (editor), St. Peter's Hospital for Stone, 1860-1960, E. \& S. Livingstone, 1960; and on St Mark's, see Lindsay Granshaw, St. Mark's Hospital, London: the social history of a specialist hospital, London, King's Fund, 1985. 


\section{The meaning of fractures}

consultant surgeon to the Ancoats Hospital, well illustrates his enthusiasm for Bostonian orthopaedics and for the organization and thrust of American medicine and surgery in general. ${ }^{19}$ It was an enthusiasm not easy to lose.

The Ancoats Hospital was only a small voluntary hospital-a typical place for a junior appointment - but in many ways it was ideally suited to a surgeon with budding orthopaedic interests. For one thing, both of the other surgeons, John Morley (later Professor of Surgery at Manchester University) and W. R. Douglas (later a renowned cancer surgeon at Manchester's Christie Hospital) were also young, ambitious and willing to try out new ideas and techniques. For another, the situation of the hospital, in one of Manchester's densest industrial districts, rendered it essentially an accident hospital with a large turnover of fracture cases. ${ }^{20}$ Finally, and not least, the hospital had a relatively liberal board of managers.

Here, then, was a propitious setting in which to try out American-style reforms, and within months of his appointment, Platt was conspiring with Morley and Douglas to do just that. Instead of each taking all the cases admitted during a period of duty, the three colleagues divided cases (and the seventy-five beds) according to surgical specialities. By this means, Platt was able to establish a uniformity of therapeutic control over all the incoming fracture (and other orthopaedic) cases. ${ }^{21}$

None of this brought rebuke from the lay managers of Ancoats, though when Platt was appointed he had had to promise not to indulge only in specialist work. Since the specialization he was proposing could be seen as meeting the needs of the publicespecially the needs of the locality's industrial workers, who were also (through workers' contribution schemes and the Hospital Saturday Fund) an increasingly important source of hospital funding - the lay governors had no reason to fear that the specialization would serve only professional interests. ${ }^{22}$ It may have been important, too, that the governors could see the specialization as emerging from the co-operative efforts of their own consultants, rather than as something imposed from outside and challenging their autonomy. The secretary of the hospital, far from expressing worry over the new division of labour, was apparently more concerned about the effect of orthopaedic specialization on Platt's own financial future, since, as everyone knew, fractures, no less than chronic musculo-skeletal deformities, were primarily the lot of the poor and therefore held out little promise for remunerative private practice-the

19 'Orthopaedic surgery in Boston', Medical Chronicle, March 1914, 58: 473-479. See also Morris Vogel, The invention of the modern hospital: Boston, 1870-1930. Chicago, University of Chicago Press, 1985, pp. 63-65; and Clement A. Smith, The Children's Hospital of Boston, Boston, Little, Brown, 1983, ch. 12:

${ }^{20}$ The average was thirty new fracture cases a week: Platt, 'On the organisation of a fracture service', Lancet, 1921, ii: 620-621, repr. in Platt, Selected papers, op. cit., note 5 above, pp. 1-5. On the Ancoats Hospital, see John Pickstone, Medicine and industrial society: a history of hospital development in Manchester and its region, 1752-1946, Manchester University Press, 1985, pp. 145-146 et passim.

${ }_{21}$ For an example of the traditional routine (at Guy's Hospital) see Layton, op. cit., note 15 above, pp. 21, 73; for earlier, at St. Bartholomew's Hospital, (where "the dresser takes all the Fracture cases etc."), see the letter of James Taylor quoted in John West, The Taylors of Lancashire: bonesetters and doctors, 1750-1890, Worsley, H. Duffy, 1977, pp. 66-67.

${ }^{22}$ On the importance of workers' contributions see anon., History of Ancoats Hospital, 1873-1900, [Manchester, n.p., n.d.], p. 34; and (Cave), Interim Report of the Voluntary Hospital Committee, 1921, Cmd. 1206. On the growing fear among the lay trustees of hospitals over the professionalizing ambitions of their medical staffs, see David Rosner, A once charitable enterprise: hospitals and health care in Brooklyn and New York 1885-1915, New York, Cambridge University Press, 1982, p. $10 \mathrm{ff}$. 
main benefit from honorary hospital appointments. ${ }^{23}$ This financial aspect may also help to explain the willingness of Morley and Douglas to comply with Platt's reformism, as may the fact that fractures, when not regarded simply as an unchallenging area of medicine, were seen as professionally risky-a case of mal-union having the potential to ruin a surgeon's reputation. ${ }^{24}$

The strategic potential for rising specialisms in the smaller hospitals (at least in the Manchester region) was also illustrated at the Salford Royal Hospital, where Platt's friend and wartime colleague, Geoffrey Jefferson, was allowed to concentrate on neurosurgery. ${ }^{25}$ But it was much more difficult for orthopaedists to carve out specialist niches in the major teaching hospitals where their interests threatened the physical territory (beds) and the confidence claims of general surgeons. In some London hospitals, orthopaedic departments were established from just before the war. But these were largely for chronic cases, rather than the victims of accidents, and were under the control of general surgeons rather than aspiring specialist surgeons. In fact (as we will see below), one of the staunchest opponents of the orthopaedic specialists in the 1920s was George E. Gask, who in the 1900s had himself been Chief Assistant to the Orthopaedic Department at St Bartholomew's Hospital. ${ }^{26}$

During World War I, Platt was deeply involved with Manchester's military orthopaedic centre at Grangethorpe; his plans for Ancoats were delayed a little, but his experience was enlarged and his commitment to "progressive orthopaedics" strengthened. ${ }^{27}$ After the war, between 1919 and 1921, Platt was able to establish the world's first segregated fracture service under the control of an orthopaedic surgeon. He carried over into civilian practice the main wartime lessons of effective fracture treatment: segregation, expert supervision, team-work, continuity of treatment, and appropriate after-care. To these features he added detailed record-keeping on the social and medical condition of patients, a technique he had learned in Boston and which, applied generally, was basic to the scientific management of American hospitals. ${ }^{28}$

\footnotetext{
${ }^{23}$ Platt, typescript of interview with Stella Butler, 6 November 1981. Though Platt aspired and eventually succeeded in following Robert Jones in building up a lucrative private practice in orthopaedics among the upper classes (a possibility for no more than one or two orthopaedists in any major urban centre outside London), initially he derived income by performing the occasional appendectomy, conducting coroner's post-mortems, assisting private surgeons, medical coaching, and by writing medico-legal reports. The financial disincentive to specializing in hospital fracture work was the reason why Platt and his orthopaedic colleagues came to endorse a salaried service for hospital consultants (see below).

${ }^{24}$ Well known was the warning of medical lecturers: "Pay great attention to your fracture cases, with them alone the grave does not cover your mistakes." Quoted in Layton, op. cit., note 15 above, p. 73.

${ }^{25}$ On the Salford Royal, see Pickstone, op. cit., note 20 above, p. 145; on Jefferson (who was a member of the BOA from the early 1920 s, and who opened the discussion on 'Fractures of the spine' at the orthopaedic meeting at the Royal Society of Medicine in 1927 [Br. med. J., ii: 1152-1153]), see his obituary in Br. J. Surg., 1961, 48: 586-588, and Biogr. Mem. Fellows R. Soc., 1961, 7: 127-131.

${ }_{26}$ J. L. Thornton, 'Orthopaedic surgeons at St. Bartholomew's Hospital, London', St Barts. Hosp. J., 1955, 59: 195-204, at p. 200.

${ }^{27}$ See P. Gray, 'Grangethorpe Hospital Rusholme, 1917-1929', Trans. Lancs. \& Ches. Antiquarian Soc., 1975, 78: 51-64. On the orthopaedic lessons of the war, see Jones, op. cit., note 7 above; S. M. Smith, 'Fractures of the lower extremity', in W. G. Macpherson, et. al., (editors), Medical services in the history of the Great War: surgery of the war, vol. 2, London, HMSO, 1922, pp. 339-380, at p. 353; and G. M. Levick et al., 'Organisation for orthopaedic treatment of War injuries', ibid., pp. 381-408.

${ }^{28}$ On the profound significance of record-keeping in the reform of American hospitals, see Rosner, op. cit., note 22 above, p. 55 et passim. On the history of record-keeping (largely as pioneered at the MGH), see S. J. Reiser, 'Creating form out of mass: the development of the medical record', in E. Mendelsohn (editor),
} 


\section{The meaning of fractures}

These were the essential principles of the "ideal fracture service" which Platt reported in the Lancet in 1921; they were to be reiterated in the barrage of papers and lectures issued by orthopaedists from the mid-1920s to the 1940s; and they were to receive the backing of the medical establishment in the BMA's highly influential 'Report on fractures' (1935). Directly as a result of this report, a motion was passed in the Commons in April 1936 which led to the setting-up of the government's Inter-Departmental Committee on the Rehabilitation of Persons Injured by Accidents, under the chairmanship of Sir Malcolm Delevigne. Through Delevigne's Interim and Final reports of 1937 and 1939 respectively, official endorsement was given to the principles first implemented by Platt. ${ }^{29}$

\section{CAMPAIGNING FOR THE CAUSE}

The long interval between the establishment of the fracture clinic at Ancoats and the publication of the above reports strongly suggests that example alone was not sufficient to make the treatment of fractures a public issue. Nor would it be right to maintain that consciousness was raised merely by the rhetoric of zealous orthopaedists. Nevertheless, the rhetoric of the few, but influential, orthopaedists to whom this paper refers, was all-important, for it was largely on the basis of their claims about the opposition to segregated fracture treatment (more so than by any extolling of new technologies or esoteric operative techniques and skills), that the campaign for the orthopaedic control of fractures was conducted. Platt's recollection is illuminating in this respect: "In the years between the wars the field of orthopaedics was to those of us then young an expanding universe, and we fought the battle for the control of fractures with gusto.... Our opponents often accused us of adopting the attitude of the German philosopher Nietzche [sic] - 'that a good fight sanctifies a cause'." 30 Thus cast, the fracture cause was more than merely the bid of a specialist group for hospital space; it was recognizably a part of a wider movement against the obstacles to reform in British hospital medicine.

Among the more important of the battles for the control of fractures was that precipitated by Robert Jones through a published lecture delivered in Liverpool in May 1925. . $^{11}$ Regarded by friend and foe alike as a "slashing attack on the 'Methods by which fractures are dealt with at the big teaching hospitals' ", Jones's lecture had, in fact, been encouraged by Platt and his close companion, W. Rowley Bristow of St Thomas' Hospital, who was largely responsible for spearheading "the attack on the idealogical [sic] barricades of the London teaching hospitals". 32

\footnotetext{
Transformation and tradition in the sciences: essays in honor of I. Bernard Cohen, New York, Cambridge University Press, 1984, pp. 301-316. "Team work" signified more than the obvious co-operation of physiotherapists, electrotherapists, plaster sisters, etc. To use the concept was to question the necessity of competition (either between surgeons, [cf. below notes 90, 97], or between hospitals) for progress in medicine.

${ }^{29}$ For Platt's article see note 20 above, and for the BMA Report see note 17 above. On the setting up of the Delevigne committee, see Public Record Office (hereinafter PRO): ED/50/173, and for discussion of the reports see the last section of this paper.

30 'British Orthopaedic Association: first founders' lecture', J. Bone Jt Surg., 1959, 41B: 231-236, repr. in Platt, Selected papers, (note 5 above), pp. 116-125 at p. 124.

31 'Lady Jones' lecture on crippling due to fractures: its prevention and remedy', Br. med.J., 1925, i:909-913.

32 Platt, op. cit., note 30 above, p. 124; and see Bristow's attack on the London teaching hospitals in his 'The influence of war surgery on treatment of fractures in Great Britain', J. Amer. Med. Ass., 3 December 1927: 1920-1924.
} 
Jones opened his lecture with the observation that the existing treatment of fractures was "a blot upon our surgical escutcheon". He decried as "hopelessly wrong" the situation existing in "the big teaching hospitals" where out-patient ambulatory fractures were treated by impermanent and unsupervised junior medical officers, and where in-patient fractures-ostensibly of little interest to honorary surgeons who resented them for blocking beds-were left to the care of house surgeons whose job consisted simply of putting up the fractures in plaster and sending patients out at the first opportunity- "A more unscientific and certainly less satisfactory method it is not easy to conceive". ${ }^{33}$ And he portrayed "as even more pathetic" the fate of those fracture cases sent to Poor Law infirmaries that were totally unfitted for the modern treatment of fractures. Yet (and this was typical of most of his fellow-advocates of fracture clinics), Jones had few statistics to offer as evidence for the general surgeons' "old bad way" of treating fractures. Indeed, their badness, he maintained, "[did] not admit of argument". Nor did he anywhere make the claim for specialized fracture treatment on the basis of orthopaedic access to new techniques or skills-he himself was never more than a weak advocate of the open-plating of fractures-nor did he extol the benefits of X-rays, though he was a pioneer in their use. ${ }^{34}$ Convinced that better functional results in fracture treatment would come from their being handled by properly trained experts, he could refer only to the principles of care worked out during the war, which had resulted in a reputed twenty per cent reduction in mortality from fractures.

Such rhetoric did more than merely represent fractures as a major surgical problem to be solved by hospital fracture clinics like Platt's at Ancoats. Knowing that his demand for "efficient" fracture services would be seen as the call for the entry of orthopaedic specialists into the major hospitals, and hence as an assault on convention, Jones pulled out every stop to legitimate exactly that. Claiming that what he was suggesting was "neither difficult in conception nor revolutionary to bring into effect", he made light of "the natural inclination on the part of the general surgeon to resist what he fears to be an encroachment of specialism", arguing that this fear was a thing of the past and that general surgeons were, for a variety of reasons, only too willing to hand over their fracture cases: "The average hospital surgeon takes neither pride nor scientific interest in the treatment of fractures. He knows it himself, his house-surgeons know it, and so do the students. Wherein and with whom lies an advantage? No! it is not a mere matter of the encroachment of specialism, but a call to our sense of proportion and sense of duty. Whether we use the term 'specialism' or not, there is no mind so comprehensive that it can keep pace with all the requirements of modern surgery."

33 Jones, op. cit., note 31 above, p. 910 . The complaint about fractures treated by unqualified persons was not new; it was linked to the late-nineteenth-century campaign for the reform of out-patients' departments. See, for example, Br. med. J., 1874, i: 777-778. Likewise, with the need for "continuity of treatment", the City Orthopaedic Hospital, London, was priding itself on this practice as early as 1905: see Annual Report, p. 12.

${ }^{34}$ For his views on open-plating, see the sources in note 8 above, and on the use of $X$-rays, see his comments in Br. med. J., 1912, ii: 1594, and 1925, ii: 319. For his role in the introduction of X-rays in Britain, see Watson, op. cit., note 9 above, pp. 87-88. The radiologist James F. Brailsford dedicated to Jones his The radiology of bones and joints, London, Churchill, 1934. 
With regard to the introduction of orthopaedics into the "already too overcrowded" medical curriculum (and hence orthopaedists into the teaching hospitals), Jones subtly side-stepped the issue by arguing in general for the benefits of a reformed teaching structure that would simplify and clarify instruction and make it more efficient. Perhaps recalling his own training under the guidance of his uncle, Jones argued for intensive training under experts, and (in fact echoing a late-nineteenth-century debate) extolled the out-patients' department as affording students "a better equipment in after-life than academic lectures, the matter of which they can equally well glean from textbooks." 35 Since much of his own work had been conducted in a private accident clinic, it is not surprising that he elevated the status of the hospital territory where the vast majority of fracture cases were treated.

Finally, Jones endeavoured to nip criticism in the bud by appealing to the patient's own best interests. To urge "that our hospitals are already too crowded", he said, "is but poor comfort to a young working man sent off to a Poor Law infirmary, with a wife and family dependent upon him. It is inefficient treatment and neglect which transforms a simple fracture to a chronic deformity. It is far better for our hospital authorities to say, 'We are not prepared to treat fractures,' than that they should take on responsibilities which they cannot meet.... We cannot disguise the fact that great numbers of adult cripples are manufactured by want of adequate provision."

It was this "plain speaking", as Jones himself called it, while disclaiming "any spirit of hostility", that set the stage for the expected confrontation. This took place at the BMA meeting in Bath in August 1925 during a special session on 'Surgery and Orthopaedics' in which the discussion was on the treatment of fractures..$^{36}$ It was here that George Gask made his debut as the defender of generalism over surgical specialism. How Gask came to open the proceedings is not clear; it is known, however, that Platt and Bristow helped ensure that the session was chaired by Moynihan (an honorary member of the BOA), and that there was an illustrious audience of orthopaedists (some from as far afield as Boston and the Mayo Clinic). ${ }^{37}$

\footnotetext{
35 Jones, op. cit., note 31 above, p. 913 . Aspects of the late-nineteenth-century debate are touched on in Third Report from the Select Committee of the House of Lords on Metropolitan Hospitals, together with ... Minutes of Evidence, 1891, Cmd. 457, p. 34. Hospital out-patient departments were typically places where there was more scope for medical interests over those of hospital governors, and where junior medics and aspiring specialists could begin to establish themselves: see Adrian Forty, 'The modern hospital in England and France: the social and medical uses of architecture', in Anthony D. King (editor), Buildings and society, London, Routledge, 1980, pp. 61-93 at pp. 76-77; see also 'The reform of the hospital out-patient department', Br. med. J., 1913, i: 403-404.

36 'Discussion on the treatment of fractures: with special reference to its organization and teaching', ibid., 1925, ii: $317-331$.

${ }_{37}$ Among the Americans present was Robert Osgood, the close friend of Jones and Platt who, in 1922, became Chief of the Orthopaedic Service at Boston Children's Hospital and Professor of Orthopaedic Surgery at Harvard Medical School. In 1921, Osgood had organized a two-day conference on the treatment of fractures at the MGH, which succeeded in bringing together over fifty general surgeons and orthopaedists (see obituary of Osgood, J. Bone Jt Surg., 1957, 39A: 726-733). From the Orthopaedic Service of the Mayo Clinic (est. 1912) came Melvin Henderson, a general surgeon who, in 1911, had been sent by the Mayo brothers to train under Jones in Liverpool and under Harold Stiles in Edinburgh (see Sketch of the history of the Mayo Clinic and the Mayo Foundation, Philadelphia, Mayo Clinic, Division of Publications, 1926, pp. 42-43). From the Montreal General Hospital (where a fracture service had been established in 1919) came A. T. Bazin.
}

The discussion at Bath appears to have prompted the questionnaire sent out by the American 
Though Gask (by this time the Director of the Professional Surgical Unit at St Bartholomew's Hospital) was hardly a conventional opponent of specialization, it was almost impossible for him to emerge from the proceedings at Bath as other than a "quixotic [defender] ... of a losing cause". ${ }^{38}$ If this indeed was the "role" that the organizers of the meeting intended for him, he filled it admirably, for by deprecating the "artificial and totally unnecessary separation between surgery and medicine" as "the greatest blow the profession ever sustained", he presented himself as a backward-looking "romantic" radically at odds with the reformist "scientific" outlook of the orthopaedists. ${ }^{39}$ To the modernists in orthopaedics who imagined "progress" in explicitly Spencerian terms of greater efficiency through greater division of labour, ${ }^{40}$ Gask could only retort that the extended division of labour which served the needs of the munitions factory hardly applied best to the manufacture of good general practitioners. But for the orthopaedists, the education of general practitioners (for which Gask mostly spoke) was neither here nor there; they linked the appalling (albeit meagre) statistics on bad fracture treatment in Britain with the fact, made clear at the meeting, "that probably one half of the fractures in this country were treated at home or in cottage hospitals by general practitioners", and concluded that fractures needed to be treated under their own expert supervision. ${ }^{41}$

The incompetence of general practitioners was to become a larger part of orthopaedic rhetoric in the 1930s, though it was never to move to centre stage (nor were there ever to be statistics on either the extent of the treatment of fractures by general practitioners or on their clinical results). So far as one can tell, general practitioners

orthopaedist, John Prentiss Lord, in which evidence was sought for the merits of hospital fracture services in the hands of orthopaedists. Lord's highly favourable findings constituted the basis of his address to the section of orthopaedic surgery of the AMA in 1927, which, in turn, was the basis for the editorial on fracture treatment in the Br. med. J.. See Lord, 'Factors in the advancement of orthopaedic surgery', J. Amer. Med. Ass., 27 August 1927, 651-654; and 'The treatment of fractures', Br. med. J., 1927, ii: 695.

38 Platt in the 'Discussion on fractures', op. cit., note 36 above, p. 325.

${ }^{39}$ Gask, ibid., p. 318. Gask's point of reference was Sir T. Clifford Allbutt's The historical relations of medicine and surgery, London, Macmillan, 1905. Though Gask emerged poorly from the meeting at Bath, he was not a representative of the old guard general surgeons. He succeeded Moynihan as chairman of the $B r . J$. Surg.; and although he was probably partly responsible for St Bartholomew's Hospital not having a fully segregated fracture service until after the Second World War, in the 1930s, he took his staff to visit Reginald Watson-Jones' orthopaedic unit (and foremost fracture service) at the Liverpool Royal Infirmary. See Geoffrey Keynes, The gates of memory, Oxford University Press, 1983, p. 264 (Keynes was Gask's chief assistant). See also the entry on Gask in the Dictionary of National Biography. Gask's outlook has much in common with the turn-of-the-century physicians described by Christopher Lawrence in 'Incommunicable knowledge: science, technology and the clinical art in Britain 1850-1914', J. contemp. Hist., 1985, 20: 503-20, esp. at p. 512; and idem., 'Moderns and ancients: the "new cardiology" in Britain 1880-1930', Med. Hist., Suppl. No. 5, 1985, pp. 1-33, esp. at p. 8.

${ }_{40}$ See, for example, Melvin Henderson, 'Leadership in orthopaedic surgery', J. Bone Jt Surg., 1934, 16: 495-498.

${ }^{41}$ W. McAdam Eccles, in the 'Discussion on fractures', op. cit., note 36 above, p. 329. The 1912 BMA 'Report on fractures', op. cit., note 8 above, revealed that over one-third of all simple fractures treated in Britain (mostly in hospitals) resulted in malunion and/or poor functional results. At the same time as seeking to take fractures out of the hands of general practitioners, orthopaedists produced primers for them which stressed the legal risks and the hostile public reaction to maltreatment: e.g., C. Max Page and W. Rowley Bristow, The treatment of fractures in general practice, London, Oxford Medical Publications, 1923; and W. H. Ogilvie, Treatment of fractures in general practice, 2 vols., London, J. Bale, 1932. Since orthopaedists relied on general practitioners to refer crippled children to their clinics, there was reason not to antagonize them. 
(unlike some hospital general surgeons) did not feel threatened by the advent of fracture specialists, ${ }^{42}$ nor had most of them much reason to be, since to refer a patient to a specialist or to a special hospital department was not to lose that patient from one's "panel" list or to forfeit National Insurance remuneration. Orthopaedists, for their part, thus had little reason not to continue to regard the consultant opponents of specialization as the main targets of their rhetoric. However, after the meeting at Bath, they tended to keep off the issues of specialization and education per se, and to focus instead on what they rightly regarded as virtually "unassailable" by anyone: the practical means to achieving the best possible functional results in the treatment of fractures. This was how Jones pitched his reply to Gask, and, by 1928, when the budding proponent of fracture services, Ernest Hey Groves, delivered his presidential address to the BOA 'On the Treatment of Fractures', it was above all this less contentious, practical side of the issue that was emphasized as "the problem" ${ }^{43}$ The solution to the problem, it was increasingly stressed, was "not new knowledge"-least of all new technology or new research into methods for the internal or external fixation of fractures-but merely "the organized application of the knowledge we already possess", namely, the "segregation of cases, the training of team workers, and the systematic tabulation of results". Left unspoken were the political implications of this application of knowledge from the point of view of the organization and structure of British hospitals. Left unspoken, too, it should be added, was the shrinking market for orthopaedists consequent upon the success of the orthopaedic scheme for crippled children combined with the declining incidence of rickets and "surgical tuberculosis" of the bone and joints. ${ }^{44}$

\section{THE CAUSE IN CONTEXT}

The debate at Bath is a good illustration of how specialization was negotiated in post-war Britain. But far wider issues were also involved here. Close to the surface of the debate, and in the fabric of its rhetoric, lay the pressing question of the health services reform.

The early 1920 s were, by and large, a period of retrenchment in health care, but the financial crisis that lay behind that retrenchment also provided an increasingly compelling argument for fundamental change. Although in 1921 the Cave Committee, in its Report on voluntary hospitals, mostly sought only to shore up the existing system,

\footnotetext{
42 See editorials in the Practitioner, 1936, 137: 402-403, and the Medical Officer, 26 June 1937, 255. The Lancet in its editorial on 'The fracture problem' (1935, i: 383-384) rightly criticized the BMA Report on fractures for completely avoiding the question of "the function of the GP in his duty to his middle-class patients [sustaining fractures]". The criticism was never dealt with: see note 97 below.

${ }^{43}$ Groves, 'The treatment of fractures: a problem of organization', Br. med. J., 1928, ii: 993-995. Groves's stress on organization in fracture work is all the more impressive for his having previously undertaken research into bone repair and open operations; see his On modern methods of treating fractures, Bristol, John Wright, 1916. For Jones's reply to Gask, see discussion at Bath, op. cit., note 36 above, pp. 319-322.

${ }^{44}$ Abundant evidence of this decline in the incidence of rickets and tuberculosis of the bone and joints is contained in the proceedings of the 'Joint Conference, Invalid Children's Aid Association and Central Committee for the Care of Cripples [Nov. 1926]', Cripples' J., 1927, 3: 162-291. Reflecting this decline is the fall in cases of bone and joint tuberculosis admitted to the LCC schools for the physically defective: from 254 cases in 1921, to 161 cases in 1930: GLRO:RH/HOSP/1/66.
} 
in the following year, the TUC and Labour Party, in a pamphlet on The Labour movement and the hospital crisis: a scheme for a hospital service, put forward a sweeping programme of reform. The latter's social and political impact is open to question; ${ }^{45}$ what is evident, however, is that the concepts of "continuity of treatment", "team work", and the "unification of control" over all hospital facilities and services were basic to the scheme. This similarity with the rhetoric of the orthopaedic reformers was not, of course, coincidental; it reflects, rather, the shared faith in rationalization among the reform-minded, or in the application of "system and uniformity" to apparent problems of ever-greater complexity and waste. As is well known, this faith in rationalization (an ideology informing the problems it sought to solve) was drawn more or less directly from the world of American commerce and industry where the "scientific" principles of bureaucratic management had proven themselves "rational" from the point of view of economic efficiency. ${ }^{46}$

But the campaign for the standardization and co-ordination of hospital services in Britain was more than merely the extension of the principles of rationalization as they were beginning to be applied to post-war industry, transport, and agriculture (as well as to trade unions). For the TUC and Labour Party, the call for the rationalization of hospital services was a part of a bid for an egalitarian distribution of medical power and provision in a state medical service. As such, their plans were different in principle from those contained in the Dawson Report of 1920. There were also fundamental differences of focus and concern. In the Dawson Report, the argument for rationalization was focused on general practice, rather than on hospitals, and there was little reference to accident and emergency services. In the TUC and Labour Party's vision of a unified and classless medical system, hospitals were more important, ${ }^{47}$ and the accident service was held to be the front line of medical care- the essential base to a pyramid of services ascending to university-linked national hospitals. ${ }^{48}$ To promote a uniform, co-ordinated accident system was to criticize the existing unequal, haphazard and confused hospital system. Here, as nowhere else in medicine, it could be made apparent that in order to meet the needs of patient populations it was vital and urgent-as vital and urgent as in World War I-to have a regionally co-ordinated, fully rationalized hospital system. Ideally, too, this would be a hospital system in which there would be (again as in the recent war) a salaried medical service, since there could be no scope for private practice in the treatment of acute injury.

To no group in medicine was this line of argument more pertinent than to the orthopaedic advocates of fracture services. But there was little hope of implementing

\footnotetext{
${ }^{45}$ See A. Marwick, 'The Labour Party and the Welfare State in Britain, 1900-1948', Amer. hist. Rev., 1967-8, 73: 380-403, esp. at pp. 386-390.

${ }^{46}$ See Lyndall Urwick, Themeaning of rationalisation, London, Nisbit, 1929; in specific relation to hospitals, see Rosner, op. cit., note 22 above.

${ }^{47}$ Pointedly, it was declared in a TUC and Labour Party publication of $c$. 1922: "Public hospitals when established should become the health centre or institution of each local health authority, and should provide accommodation within their walls for all medical activities." The Labour Movement and preventive and curative medical services: a statement of policy with regard to health, London, TUC and Labour Party, [n.d.], p. 6. On the Dawson Report, see the minutes of the Consultative Council, PRO: MH/73/38-49, and Frank Honigsbaum, The division in British medicine, London, Kogan Page, 1979, ch.6.

48 The Labour Movement and the hospital crisis, TUC and Labour Party, 1922, p. 7. See also 'The Labour Party and the hospital problem, conference at Caxton Hall', Br. med. J. suppl. 3 May 1924: 213-222.
} 
such schemes in the financial climate of the early 1920s. Although the TUC and Labour Party proposals shifted the focus of reform on to hospital services rather than general practice, for accident services to be an effective instrument of rationalization more would be required than the force of argument. Certainly, to understand how the rhetoric of the orthopaedic reformers came to have impact in the 1930s, it is important to appreciate not just the wider political context of reform, but also the more immediate external pressures that were increasingly coming to bear on the reform of accident services. In particular, reference can be made to the 1924 Report on the disposal of ambulance cases; to the growth of concern over the incidence of motor vehicle accidents; and to the influential model for the handling of accident cases, the Vienna Accident Hospital.

\section{PRESSURE FROM WITHOUT}

The first of these sources of pressure in the inter-war period, the Report on the disposal of ambulance cases, was prepared by a committee of the King Edward's Hospital Fund for London-a body specifically established for the rationalization of the voluntary hospitals. Primarily concerned with the costs, distribution, and availability of hospital beds for accident cases and with the proper "relationship to be observed between ... rate-supported institutions and the Voluntary Hospitals", the report also made apparent that, for all intents and purposes, the metropolis was without an accident service. ${ }^{49}$ The LCC's Ambulance Service, which had been organized in 1915 and was attending some 24,626 calls with its seven ambulances by 1923 , was constantly faced with the problem of where to take patients. The majority of Poor Law infirmaries had no accommodation for accident cases, while most of the large voluntary hospitals were grossly underprovided. (At the Charing Cross Hospital, for instance, where 980 accident cases were received in 1923, there were only four accident beds. $)^{50}$ When contrasted with the co-ordinated accident service of some American cities, and with the elaborate system for dealing with fracture cases that had been in existence at the Massachusetts General Hospital since 1922 (which became widely known in 1925 through a joint British and American publication), ${ }^{51}$ the

\footnotetext{
${ }^{49}$ King Edward's Hospital Fund for London, Ambulance Case Disposal Committee: Report of a Special Committee, 1924. For discussion of this and other literature relating to accident and emergency services in the inter-war period, see K. S. Cliff, 'The development and organisation of accident and emergency services', DM thesis, Southampton University, 1981, pp. 38-76. See also, G. Ayers, 'Ambulance services' in her England's first state hospitals, London, Wellcome Institute, 1971, pp. 188-192; and D. T. Tugwood, 'Coventry Ambulance Service: its origins and development, 1872-1974', MA thesis, Warwick University, 1984.

${ }^{50}$ Directly as a result of the King's Fund report, and in order to secure further monies from the Fund, King's College Hospital, London, immediately added fourteen accident beds: Br. med. J., 1924, ii: 483 . The public image (and hence public funding) of voluntary hospitals was seen as jeopardized through revelations about poor accident facilities; Frank Briant, MP, pointed out to the King's Fund Committee (p. 35): “Of course, quite wrongly, the average person in the street imagines the Hospital exists for accidents. To a large extent I do not think it does; but I think it would have a very bad effect upon the finances of Hospitals if the general public had a general idea that accidents had not to be taken there, or they would not deal with them."

${ }^{51}$ P. D. Wilson (Harvard) and W. A. Cochrane (Edinburgh), Fractures and dislocations, Philadelphia and London, J. B. Lippincott, 1925, which was reviewed in the Br. med. J., 1925, i: 928-992. For background to the fracture service in Boston, see 'Discussion on fracture symposium', J. Orthop. Surg., 1921, 3: 556-559
} 


\section{Roger Cooter}

situation in London appeared antediluvian. Although the committee of the King's Fund stuck to their brief, it was evident from their report that not only was there an urgent need for "uniformity of procedure", but also for the centralization and co-ordination of accident services in London, if not for the control of these services under a single specialist group.

The second source of pressure for reform, the rise in the number of motor vehicle accidents, became prominent around the same time as the Report and, indeed, was not separate from the latter's concerns. ${ }^{52}$ It is ironic, of course, that motorization, which in the form of ambulance transport was vital to the post-war plans for accident services, was also a major cause of the injuries that were to require speedier transport. "Before the era of the motor car", commented the Lancet in 1926, "the receiving officer of a large general hospital might be embarrassed by a run of Pott's fractures on the first snowy evening of the year; today a fine Sunday evening may overwhelm any cottage hospital with a glut of complicated injuries."53 For England and Wales, non-fatal street accidents involving motor vehicles increased four-fold between 1913 and 1932: from 38,000 to 162,000 , with the most striking rise (unsurpassed until the 1950s) occurring between 1927 and $1934 .^{54}$ And, as the Ministry of Transport was acutely aware in 1928, "There are few questions, as reference to the daily press will show, which excite more constant and widespread interest." 55 Although the number of domestic and industrial accidents was greater, the socio-medical profile of road accidents was considerably higher, in part because these accidents were not confined to specific geographical areas and therefore presented severe obstacles to medical planning. ${ }^{56}$

Allied to this troublesome spatial aspect of motor vehicle accidents was the financial spectre they raised. Indeed, to most medical commentators, what mattered more than the facilities for dealing with these accidents was the problem of how to recoup from insurance companies the costs of treating the victims. The BMA reckoned that doctors were paid in only one out of five cases; and in 1931, it was estimated that some 25,000 victims of motor accidents treated as in-patients in voluntary hospitals had cost nearly

(Jones was present at this meeting). See also, Experience in the management of fractures and dislocations, by the staff of the fracture service, Massachusetts General Hospital, Boston, under the general editorship of P. D. Wilson, Philadelphia, J. B. Lippincott, 1938.

52 See the King's Fund Report p. 12, for street accidents in London.

53 'Accidents and hospitals', Lancet, 1926, ii: 864. See also Lancet, 1927, i: 463; 'Medical practitioners and road accidents', Br. med. J. suppl., 25 July 1931, 62-65; and 'Emergency treatment for road accidents', ibid., 1934, ii: 213-214. For the implication of motor accidents for cottage hospitals, see Lancet, 1931, i: 1410.

${ }^{54}$ Board of Trade: Statistical Abstracts, London, HMSO, 1934, p. 293, and W. Plowden, The motor car and politics in Britain 1896-1970, Harmondsworth, Middlesex, Penguin Books, 1973, p. 271, and Appendix D, 'Road casualties, 1928-69', p. 483.

55 Quoted in ibid., p. 252.

${ }^{56}$ Of 19, 286 fractures cases in 1937, 14.9 per cent were the result of road traffic accidents: Delevigne, Interim Report of the Inter-Departmental Committee on the Rehabilitation of Persons Injured by Accidents, London, HMSO, 1937, p. 8. A LCC inquiry into 1,068 fracture cases treated at four of their hospitals during summer and winter sample periods in 1936 and 1937 revealed that industry was responsible for 13.5 per cent (145), road traffic for 22.9 per cent (245), while 63.4 per cent (678) were the result of other causes. GLRO:PH/HOSP/1/72. In Manchester, where there were annually about 5,000 fracture cases in the early 1930s, 70 per cent were domestic, 18 per cent street accidents, and 12 per cent industrial: see Pickstone, op. cit., note 20 above, p. 287. For similar American statistics, see Roy N. Anderson, The disabled man and his vocational adjustment, New York, Institute for the Crippled and Disabled, 1932, p. 12. 


\section{The meaning of fractures}

one-quarter of a million pounds. ${ }^{57}$ This problem, which was to be taken up by Moynihan in the House of Lords in 1933, was partly solved by the Road Traffic Act of $1934,{ }^{58}$ but the general issue of recovering costs for accident victims who were covered by insurance for other than hospital medical services remained contentious (particularly so in the 1930s in relation to patients hospitalized for accidents who were in receipt of workmen's compensation benefits). Lobby groups such as the British (Voluntary) Hospitals Association were adamant that the insurance companies should be made to pay. ${ }^{59}$ There was little consideration, however, of the possible ill-effects of allowing private insurance companies to enter into medical care as independent third-parties. On the contrary; especially for those with a special interest in the treatment of injuries who felt themselves peripheral to the core of hospital medicine-above all, of course, the orthopaedic advocates of fracture services-there were evident professional benefits to be had through the exploitation of this potential source of independent funding. This was demonstrated by American hospital experience in the 1910 s and early $1920 \mathrm{~s} ;{ }^{60}$ but the example that was to outshine all others was the Vienna Accident Hospital, established (in 1925) and entirely maintained by the Austrian National Insurance Company. A more positive influence than either the report of the King's Fund or the concern with motor accidents, the Vienna Accident Hospital also had a more decided effect on the orthopaedic advocates of fracture clinics.

\section{BÖHLER'S ACCIDENT HOSPITAL}

The Vienna Accident Hospital was a fully equipped 125-bed institution that had been organized by Lorenz Böhler, a general surgeon who had developed a special interest in the treatment of fractures during the war. Like Platt, Böhler had become a propagandist of segregated fracture treatment, and he too appreciated the need to attend to the arguments of the opponents of this specialization. Thus, through an impressive accumulation of statistics, unique for the time, Böhler was to prove not only that fracture cases were better and more economically treated in his hospital than elsewhere, but also, that, despite the large number of cases he treated, his specialist work posed no threat to the supply of fracture cases to general surgeons in

\footnotetext{
${ }^{57}$ Plowden, op. cit., note 54 above, p. 276. For statistics on the victims treated and the costs recovered in Manchester and Salford in 1932, see Pickstone, op. cit., note 20 above, p. 273.

58 The Road Traffic Act provided for payment up to a maximum of $£ 5$ for out-patient cases and $£ 50$ for in-patient care. A fee of $12 \mathrm{~s}$. $6 \mathrm{~d}$. per patient was payable by the user of the car to the doctor or hospital who first attended the case. Delevigne, op. cit., note 56 above, Final report, London, HMSO, 1939, pp. $102-103$. See also, 'Emergency treatment for road accidents', Br. med. J., 1934, ii: 213-214.

59 See, 'Memorandum of Evidence by the British Hospitals Association', in Minutes of Evidence taken before the Royal Commission on Workmen's Compensation, London, HMSO, 1939, 1940, p. 1078ff. See also, (Cave) Voluntary Hospitals Committee, Final Report, 1921, Cmd 1335, p. 28, and Ḧey Groves, 'Treatment of fractures', Br. med.J., 1928, ii: 995. The voluntary hospitals were in the most vulnerable position since, unlike the municipal hospitals, they were not empowered to recover costs.

${ }^{60}$ See Cave Report, op. cit., note 59 above, p. 28; and Vogel, op. cit., note 19 above, pp. $121 \mathrm{ff}$. The insurance companies began to act as a third party in medicine in 1911 after Massachusetts introduced Workmen's Compensation. See also Rosner, op. cit., note 22 above, p. 94.
} 


\section{Roger Cooter}

Vienna's major teaching hospitals. ${ }^{61}$ From this statement alone it is possible to grasp some of the reasons why, long before 1931 when Böhler was invited to address the annual meeting of the BOA, his hospital had become internationally famous. ${ }^{62}$ As was made clear in the editorial on 'Accidents and hospitals' in the Lancet in 1926, the implications of Böhler's work for British medicine were as profound socially, economically and medico-politically as they were therapeutically. ${ }^{63}$ Not only had Böhler demonstrated the clinical advantages of specialized fracture treatment in restoring patients to their full earning capacity, and hence proved the social value of this work, but also, while proving to the insurance companies that surgical specialization could render enormous savings, he had further demonstrated to enterprising hospital administrators that such specialization could be a paying proposition. That the Vienna Accident Hospital had "saved the insurance societies something in the neighbourhood of $£ 18,000$ " was just the sort of "astonishing" fact to stimulate interest in the whole question of accident services and, at the same time, to draw attention to the "grave scandal" that in Britain the insurance companies "contribute nothing towards the treatment of their injured clients in hospital". "Both equity and self-interest alike", the Lancet maintained in its editorial, "should lead the companies to support an accident department in every hospital".

Not surprisingly, it was precisely this conclusion that was also insisted upon by the orthopaedic advocates of segregated fracture services, who naturally found in Böhler's work a great source of justification for their professional cause. Ernest Hey Groves, who was more insistent than most about the need to convince British insurance companies "that organisation of fracture treatment would effect so much saving in compensation as more than to cover the costs of treatment", 64 translated Böhler's work on fractures into English. In his preface, he noted that Böhler had "demonstrated that the proper treatment of fractures is not only a scientific problem or a philanthropic duty, but also a business proposition. In other words, it pays to treat fractures well!"65

Because the legitimation of orthopaedic specialization was implicit in any discussion of Böhler's work, orthopaedists, once having made the economic point, served their interests further merely by extolling Böhler's therapeutics. But, like an earlier generation of visitors to the clinic of Thomas and Jones in Liverpool, the orthopaedic visitors to Böhler's clinic were less impressed by his various surgical and manipulative techniques (though many of these were praised as "revolutionary" and their results

${ }^{61}$ Böhler, The treatment of fractures, trans. by M. E. Steinberg, Vienna, Wilhelm Maudrick, 1929, preface; Platt, 'Orthopaedics in Europe', op. cit., note 5 above, pp. 84-85. Böhler, The treatment of fractures, 4th English ed. trans. from the 4th enl. and rev. German ed. of 1933, Bristol, J. Wright, 1935, p. 538.

62 See, for example, C. V. Mackay, 'Dr. Böhler's Fracture Clinic in Vienna', Br. med. J., 1935, i: 522. Platt and Bristow visited Böhler's clinic in 1929 on behalf of the BOA, see, 'The log of Vienna, 26-29 September 1929', MS typescript, BOA archives, Royal College of Surgeons. For Böhler's visit to England, see, J. Bone Jt Surg., 1931, 13: 382-383. A visit to Böhler's clinic was regarded as a badge of progressivism among orthopaedists in the 1930s and was often symbolized (as in Platt's case) by the adoption of the use of plaster-of-Paris. T. Porter McMurray, one of Jones's successors in Liverpool, continued to use splints rather than plaster in the 1930s, "never having visited Böhler's clinic"; Platt, interview with the author, 7 November 1984.

${ }^{63}$ Lancet, 1926, ii: 864 . See also ibid., i: 383 , where Böhler's clinic is described as having become "a mid-European fracture synod".

64 'The organization of the treatment of fractures', Br. med. J., 1935, i: 817.

${ }^{65}$ Böhler (1935), op. cit., note 61 above, p.i. 
described as "startling"), than by his meticulous organization. ${ }^{66}$ Böhler himself regarded his organization for the overall control of fracture treatment as the secret of his success, and specifically likened it to the progress of rationalization that in recent years had rendered industry, transport, and agriculture more efficient. It was by means of the subdivision of the labour process, he insisted, that the parts of medical treatment were simplified and greater efficiency resulted. ${ }^{67}$

But for two very obvious reasons, the proponents of segregated fracture services had to be highly selective in their use of Böhler's model. First, his hospital was intended not just for fractures, but for accident cases of all kinds. References to the hospital did not therefore automatically serve the interests of those seeking to expand their professional space on the basis of fracture treatment alone. Although in selected industries and industrial regions in Britain, fractures predominated over other injuries, in general only about ten per cent of all cases of injury involved fractures ${ }^{68}$ Thus arguments for the segregation of accident cases did not necessarily compel a commanding role for orthopaedists, nor even necessitate their employment in accident services.

The other reason why orthopaedists had to be selective in their use of the Böhler model was that Böhler's hospital was a separate institution. As such it hardly furthered the orthopaedists' main ambition of securing for themselves and their specialism a permanent niche within teaching hospitals. The last thing that British orthopaedists wanted was to end up like Böhler, "cut off entirely from general hospitals and cut off entirely from the general surgical and medical staffs [and students]". ${ }^{69}$ That at the meeting at Bath it had been George Gask who had warmly endorsed the idea of an accident hospital for London would have been warning enough to most orthopaedists to keep firmly before them the object of securing fracture clinics within general hospitals. ${ }^{70}$

Yet it was not by rejecting outright the idea of accident hospitals that those interested in segregated fracture treatment in Britain established the priority of their

${ }^{66}$ Ibid., p.i. For comments on the therapies and the impressive results, see Bick, op. cit., note 1 above, pp. 293-294; W. H. Ogilvie, 'Physiology and the surgeon', Edinb. med. J., 1936, 43: repr. in his Surgery: orthodox, and heterodox, Oxford, Blackwell Medical Publications, 1948, pp. 147-167 at p. 152; and Platt, 'The evolution of the treatment of fractures', Manchester Univ. Med. School Gaz., 1938, 17: 56-62 at p. 59.

${ }^{67}$ Böhler (1935), op. cit., note 61 above, p. 14ff.

${ }^{68}$ Delevigne, Final report, op. cit., note 58 above, p. $14 \mathrm{ff}$. See also, for 1935, statistics on the incidence of fractures at 33 LCC hospitals, in GLRO:PH/HOSP/1/72.

${ }^{69}$ T. P. McMurray in the discussion on the paper by H. E. Moore, 'Avoidable wastage in connexion with industrial injuries', Lpool med.-chir. J, 1933, 41: 19-50 at p. 38. McMurray, however, was in favour of central hospitals for traumatic surgery and rehabilitation, such as Robert Jones had proposed in 1923 to the West Derby Board of Guardians for the conversion of the Alder Hey Poor Law Infirmary. One of the few persons on the BMA Fracture Committee to endorse the accident hospital concept was W. McAdam Eccles, colleague of Gask and surgeon to the Orthopaedic Department at St Bartholomew's Hospital (1903-12) before becoming a consulting surgeon specializing in fractures. He advocated establishing a Böhler-like industrial accident clinic at the British Postgraduate Medical School at Hammersmith. See discussion in Donald C. Norris (Principal MOH to the Bank of England), Presidential Address to the Hunterian Society, 'Some medical problems in accident insurance', Trans. Hunter Soc., 1937-8, 2: 10-36, at p. 32. An earlier dissenting voice against fracture clinics, as opposed to trauma centres, was that of Professor A. W. Sheen of Cardiff, in the discussion at Bath in 1925, op. cit., note 36 above, p. 327. The problem of specialist services isolated from one another by function, administration, and personnel was apparent to those compiling the Hospital Surveys in the 1940s, as Sir George Godber has recently recalled: lecture, Manchester, 4 December 1984.

${ }^{70}$ As recalled, significantly, in an editorial on 'The treatment of fractures', Br. med. J., 1927, ii: 695. In America in the 1930s, orthopaedic surgeons were increasingly fearful that their specialism would be diluted and its borders blurred if too much work was devoted to the "attractive and lucrative treatment of traumatic 


\section{Roger Cooter}

claims. Rather, it was by putting accident hospitals forward as one option among others that, at one and the same moment, they exploited the wider social and political issue of accident services, and served their own interest in hospital fracture services. To do this, the orthopaedic reformers simply reinforced the point made by the Lancet in 1926, that the administrative difficulties and costs involved in establishing separate accident hospitals made it more sensible to try to develop accident departments in existing general hospitals. ${ }^{71}$ While explaining the difficulties involved in establishing separate accident hospitals, they revealed the economic viability of hospital fracture clinics. This was how Hey Groves presented the case for fracture clinics to the LCC in the mid-1930s. ${ }^{72}$ Around the same time, in an address on 'Broken bones and money wasted' to the National Safety Council, he proceeded further along the road to making an economic virtue of necessity: "To avoid all the muddle and inefficiency it was not necessary first to provide a large special hospital devoted to accidents [The Times reported]. The principles of organisation were comparatively simple and cheap; they required no new buildings nor any capital expenditure." ${ }^{, 73}$ Hence, when the medical officer at St James' Hospital, Balham, William Gissane, tried to win the LCC over to the idea of separate "Units [of 100 to 150 beds] for Traumatic Surgery" instead of "fracture clinics", and offered to take a $£ 200$ cut in his salary in order to be able to direct such a unit, he was dismissed as an idealist and branded a bad character interested only in furthering his own career. ${ }^{74}$ "My present enthusiasm", he had explained, "is not a mushroom growth following a hard working four week visit to Dr. Lorenz Böhler in Vienna, but that holiday showed me the Hospital of my ideals as a reality."75 In 1941, Gissane's dream came true with his appointment to the new Birmingham Accident Hospital-the only accident hospital ever created in Britain,

and occupational injuries". F. D. Dickson in his Presidential Address to the American Orthopaedic Association in 1936, who also feared "that we will lose our sense of proportion and cease to be orthopaedic surgeons and become traumatic surgeons. . . Sooner or later, our membership will have to make a decision as to what extent orthopaedic surgery and traumatic surgery can be mixed." J. Bone Jt Surg., 1936, 18: 263-269. For British orthopaedists this was a secondary consideration in the 1930s, but it loomed larger after the Second World War. See, for example, 'Discussion by Fellows of the [B.O.] Association on the relationship of orthopaedic surgery to traumatic surgery', J. Bone Jt Surg., 1949, 31B: 633-635.

71 Lancet, 1926, ii: 864.

72 SeeGLRO:PH/HOSP/1/72. Groves had reported to the LCC on the fracture problemafterstudying seven LCC hospitals in 1936 for material for his lectures on fracture organization to the British Postgraduate Medical School. Charles Hill, Assistant Medical Secretary of the BMA, wrote to William Allen Daley (Chief Medical Officer for the LCC) on 18 April 1934 (while the BMA Fracture Committee was sitting): "You deal with the larger problem of orthopaedic cases in general and had [sic] in mind particularly the administrative problems encountered as a result of the variety of agencies at work. The Fracture Committee dealing with a smaller, a clear-cut problem, is approaching its problem in a missionary spirit with perhaps a lesser consideration for administrative problems."

73 'Cooperation in first aid', The Times, 1 June 1935, p. 11. Cf. the views on separate accident hospitals offered by Sir Arnold Wilson and by Sir Walter Citrine and Dr H. B. Morgan (for the TUC) in the Royal Commission on Workmen's Compensation, op. cit., note 59 above, pp. 353, 481.

${ }_{74}$ See Gissane's letter of 30 October 1938 and the attached note by Dr Bruce (Principal MO to the LCC): “I do not say that Gissane is wrong but I feel that he is trying to rush us for personal reasons; . . . he is probably a good surgeon, but there is also some evidence that he is . . . an uncertain teacher ... [his] proposal could get him out of his present position into an anomalous one and give him, possibly, a [?] claim to one of the big jobs." GLRO:PH/HOSP/4/33.

${ }_{75}$ Letter to Dr Brander of the LCC, 31 July 1936, in GLRO:PH/HOSP/4/27. 
and itself something of an accident. ${ }^{76}$ But this was after the establishment of the Emergency Medical Service during the Second World War-after, that is, government backing had already been secured for hospital fracture services under orthopaedic control. Not until then did members of the BOA begin collectively to push for the national provision of what they at first called "Orthopaedic and Accident Services". 77 And only then was it to be said (as by Platt in 1950) that "the Vienna experiment ... has proved that within the framework of comprehensive orthopaedic schemes there is a place for the accident hospital."78 (my italics).

\section{STATE, INDUSTRY, AND ORGANIZED LABOUR}

Throughout the 1930s, orthopaedists continued to argue that the private insurance companies ought to be induced or be compelled by "legal enactment" to support fracture services. But hopes for tangible results from this quarter steadily diminished. As pointed out at a meeting in the Ministry of Health in 1930, the insurance companies were simply not interested in arguments for the more efficient treatment of fractures: "[they] simply say that so far as they are concerned, it is a question of finance, and the premiums are so regulated that they cover even the most expensive case. Any attempt on the part of the doctors or the hospitals to reduce the period of incapacity would merely mean that employers would press for a lower premium and the Insurance Company would be no better off than before. We cannot hope, therefore, for much help in the way of securing improved treatment from the Insurance Companies." ${ }^{, 79}$ The official line of the insurance companies, as the Federated Employers Insurance Association told Hey Groves in 1936, was that by the terms of the legislation on workmen's compensation, they were unable "to do anything more than pay the compensation so fixed", 80 but the real problem seems to have been the competition between the insurers themselves. A representative of one of the companies pointed out

\footnotetext{
76 The opening of the Queen Elizabeth Hospital in Birmingham left the centrally located Birmingham General Hospital vacant and available for conversion under the Emergency Medical Service. See Ministry of Health, Hospital survey: West Midlands, London, HMSO, 1945, p. 15; P. Clarkson, 'Out-patient arrangements and accident services', Guy's Hosp. Gaz., 1948, 62: 202-211 at pp. 208-209; and Alan Ruscoe Clarke, et al., 'Organisation of accident services', in Clarke et al. (editors), Modern trends in accident surgery and medicine, London, Butterworth, 1959, pp. 1-8.

${ }^{77}$ See BOA, Memorandum on Fracture and Accident Services Committee, London, 1943; see also, G. R. Girdlestone, 'A regional orthopaedic and accident service', Br. med. J., 1949, i: 720-722; and J. Trueta, Gathorne Robert Girdlestone, Oxford University Press, 1971, p. 79. For a survey of the subsequent development of orthopaedic and accident services, see Nuffield Provincial Hospitals Trust, Casualty services and their setting: a study in medical care, Oxford, 1960; BOA, Casualty departments: the Accident Committee (July 1973), which led to W. Lewin, Medical staffing of accident and emergency services: a report prepared on behalf of the Joint Consultants Committee and presented in April 1978, BMA, 1978. The latter observed that of 228 major A/E departments, 174 were under the control of orthopaedic surgeons.

${ }_{78}$ Platt, 'Orthopaedics in Europe', op. cit., note 5 above, p. 85.

${ }^{79}$ Meeting of 22 December 1930, at DrT. Carnwath's office at the Ministry of Health (a copy of the minutes of which were circulated in County Hall): GLRO:PH/HOSP/1/66. The meeting was apparently forgotten by 1936, when Sir Frederic Menzies, head of the medical services for the LCC, held a meeting on fracture clinics with Sir Malcolm Delevigne and, referring to the practice of the Metropolitan Life Assurance Company of New York, "suggested that some of the bigger London insurance companies might be approached. He thought that grants from industry or insurance companies would greatly facilitate the establishment of special fracture units by the LCC." (GLRO:PH/HOSP/1/73.)

${ }^{80}$ The Times, quoted in 'Memorandum of evidence from the British Hospital Association', Royal Commission on Workmen's Compensation, op. cit., note 59 above, p. 1078. See also, 'Memorandum of evidence from Accident Officers' Association', ibid., p. 828ff.
} 


\section{Roger Cooter}

in 1935: "while certain insurance corporations might very well be inclined to put up considerable sums for rehabilitation work they were held back by the consideration that their action would be benefiting other companies which were not contributing at all." 81

Increasingly, therefore, orthopaedists came to realize that only through state initiatives and through public funding would fracture and rehabilitation services be effectively implemented. Through their work with crippled children (which involved remuneration from the Board of Education, Ministry of Health, and Local Authorities), they were already accustomed and well disposed to the benefits of state support. The virtues of state involvement and assistance were made strikingly apparent, moreover, in the contrast between, on the one hand, the relatively positive response to accident and fracture services on the part of the county council and municipal hospital authorities and, on the other hand, the generally reluctant attitude towards them and their co-ordination on the part of the voluntary hospitals. In London, some of the larger voluntary hospitals (partly for reasons of autonomy, but mostly because of financial constraints) had actually gone so far as to make arrangements for sending their fracture cases to those LCC hospitals where segregated fracture services had been established. ${ }^{82}$ "One almost fears that nothing short of some social cataclysm, such as Communism, bankruptcy, or war, will be strong enough to break old prejudices", complained Hey Groves in 1933, after a frustrating and futile attempt to secure the co-operation of the voluntary hospitals in Bristol. ${ }^{83}$

Honigsbaum has claimed that it was the recognition of these obstacles to fracture clinics and, hence, to the place (and/or greater standing) of orthopaedists within British teaching hospitals, that led the orthopaedists to be "the 'radicals' of the medical profession" pressing for the entire reorganization of the health services. ${ }^{84}$ Such a claim is valid, at least in the absence of further detailed studies of the politics of the medical profession in this period, and especially if one is referring - as Honigsbaum is - to the outspoken Liverpool orthopaedist, fracture expert, and leading BOA political activist from the mid-1930s, Reginald Watson-Jones. ${ }^{85}$ But whether or not it is the case that

\footnotetext{
81 'Rehabilitation of the disabled', Br. med. J., 1935, i: 726. In fact, however, two orthopaedic hospitals were heavily subsidized by groups of insurers: the Harlow Wood Orthopaedic Hospital, near Mansfield, Notts., and the Manfield Orthopaedic Hospital, Northampton, both in mining districts. See Royal Commission on Workmen's Compensation, op. cit., note 59 above, p. 1084.

${ }^{82} \mathrm{See}$ J. C. Nicholson, 'Fracture of the neck of the femur, a personal experience', Br. med. J., 1938, ii: 464 466; and Hey Groves' comments on this article, ibid., 1938, ii: 633-634. The exceptions among the voluntary hospitals were the royal infirmaries in Manchester and Liverpool, the former under Platt (who in 1932 was the first orthopaedic surgeon to be appointed to the MRI), the latter under Reginald Watson-Jones.

${ }^{83}$ Hey Groves, 'A surgical adventure: an autobiographical sketch', repr. from Bristol med.-chir. J., 1933, 50: 22.

${ }^{84}$ Honigsbaum, op. cit., note 47 above, p. 240.

85 Watson-Jones was the author of the famous textbook Fractures and other bone and joint injuries, first published in 1940, and was subsequently the editor of the British volumes of the J. Bone Jt Surg. and president of the BOA (see obituary in Br. med. J., 1972, ii: 533). His early career owed much to Robert Jones, and he studied fracture treatment under Platt at Ancoats before establishing his fracture clinic at the Royal Liverpool Infirmary. In 1943, he was appointed director of the orthopaedic and accident department of the London Hospital. Involved with the Miners' Welfare Commission and TUC over the rehabilitation of workers in the 1930s (see below), he went to Russia in 1943 at the same time as the TUC delegation (see his 'Russian surgeons and Russian surgery', Br. med. J., 1943, ii: 276; and Walter Citrine, Two careers: a second
} 
orthopaedists before 1948 were "almost alone among consultants [in welcoming] ... proposals for the state control of the voluntary sector", ${ }^{86}$ this should certainly not be taken as their position in the 1930s. As revealed in Hey Groves' Harveian Oration of 1930 (delivered while he was president of the Association of Surgeons of Great Britain), what was being called for then, quite explicitly, was "State aid, which does not involve State control". ${ }^{87}$ State aid, unlike state control, was seen as the means to forcing the voluntary hospitals into becoming publicly accountable and (via the capital that hopefully would become available for the development of modern scientific techniques and procedures) to their coming further under the control and direction of "medical experts". The 1929 Local Government Act, Hey Groves believed, had "gone a long way toward making possible a general unification of the hospital system", but because the Act had left the financial structure of the voluntary hospitals intact, the lay managers of these hospitals could still use "any excuse or justification for behaving as though they controlled a proprietary institution". ${ }^{88}$ At root, therefore, state aid was the means to undermine the authority that was seen as blocking not just the particular interests of the orthopaedists but, more generally, the reformist principles they held dear and generally applicable: uniformity of procedure, co-ordination of specialist effort, and control by medical experts. Socialized medicine was clearly not the object; to seek state support for voluntary hospitals in order to facilitate their control by consultant specialists was to occupy a middle ground between voluntarism and statism - a ground potentially as free from bossy state bureaucrats and Medical Officers of Health as from proprietorial hospital governors.

The occupation of this middle ground was not unique to orthopaedists and, in fact, in his Harveian Oration, Hey Groves hardly referred to their interests specifically. Yet it was their interests above all that were served by the argument for state aid. However essential public funding was for the modernization of voluntary hospitals, it was even more essential for future specialists in fracture work, since (unlike most of the senior orthopaedic surgeons advocating fracture services in the 1930s), they could expect to have little time for remunerative private consulting. Clearly, to establish firmly and maintain the sought-after niche in the high-status voluntary hospitals, it was necessary at the same time to secure salaries on at least a part-time basis. (In view of the diminishing state-remunerated work with crippled children, this financial need was all the more pressing.) The BMA, prior to the TUC in 1922, had recommended salaries for the

volume of autobiography, London, Hutchinson, 1967, pp. 167-168, 171). However, when it came to implementing the NHS, by which time his private practice in London was large and world famous, he argued for restraint and turned against a full salaried service: "We want freedom from medical control, and that freedom demands private practice. I saw the abolition of such freedom in Russia, and it has meant the end of medical progress in that country": 'The consultant's vote', Br. med. J., 1948, i: 264-267 at p. 266.

${ }^{86}$ Honigsbaum, op. cit., note 47 above, p. 240.

87 'Should medicine be a mendicant? A review of our hospital service', Lancet, 1930, i: 1107. See also the argument for state-funded orthopaedic institutions in Ireland managed by private societies and under the control of orthopaedists: W. C. Somerville-Large, 'Study of a national orthopaedic system', Irish J. med. $S c i$., 1937, 6th ser.: 161-172, and idem., 'The orthopaedic problem in Ireland', ibid., 1935, 6th ser.: 82-88.

${ }_{88}$ Hey Groves, op. cit., note 83 above, pp. 1106, 1051. Among other consultants at this time to call for state aid without state control was H. S. Souttar, surgeon to the London Hospital, who was subsequently the Chairman of the BMA Fracture Committee. See Arthur Newsholme, Medicine and the state, London Allen \& Unwin, 1932, pp. 48-49. 
resident staffs of voluntary hospitals, but no one had recommended that consultants be "salaried". ${ }^{89}$ Before the mid-1930s, the idea was virtually unthinkable within the voluntary sector, and even in the LCC's hospitals it was not until the mid-1930s that the practice was begun on a small scale (though there were, of course, payments for consulting surgeons). ${ }^{90}$ It is hardly surprising, therefore, that Hey Groves and other advocates of orthopaedic specialization in the early 1930s did not specifically refer to the state remuneration of fracture "experts" when they urged the voluntary hospitals to enter into a relationship with the state that was not unlike that then existing for the $B B C$ and the universities. To have done so would have weakened their case in certain quarters and generally have played up the fact (appreciated by a sub-committee of the Voluntary Hospitals Committee for London in a report of 1939 on Organised fracture services for London) that "the voluntary hospitals are being called upon to play a prominent part in what is virtually a new type of service and that payment of whole-time directors of registrars will inevitably involve additional expense". 91

Connected to the reason why orthopaedists did not press for salaried service in the early 1930s (and, paradoxically, a part of the reason why thereafter they increasingly became advocates of state involvement in hospitals) was their rising hope that financial and moral support for their fracture cause might be forthcoming from the private sector-in particular from large industry. Such hopes had indeed existed from the very beginning of the fracture movement and had been nourished in the 1920s by American examples of industry-based accident and rehabilitation services. ${ }^{92}$ It was not until the early 1930s, however, as a result of a notable British example, that the orthopaedic reformers began in earnest to make their pitch to industrialists.

${ }^{89}$ Referred to in The Labour Movement and the hospital crisis, op. cit., note 48 above, p. 11. So too, Somerville Hastings' proposal that general practitioners become salaried servants of the state was rejected by the Labour Party's Advisory Committee on Public Health in the early 1930s: see Marwick, op. cit., note 45 above, p. 389. By 1939, however, there was, as Menzies stated, "a growing demand for remuneration of the 'Honorary' medical staffs": PRO: MH/80/24. In general, the more pay-patients there were in public hospitals, the greater was the demand by doctors and consultants for payment, and on these grounds, in 1935, both the BMA and the Liverpool Hospital Commission approved the payment of hospital consultants. See Political and Economic Planning, Report on the British health services, London, 1937, pp. 240-261.

${ }^{90}$ The orthopaedic surgeon, W. H. Trethowen, for instance received 200 guineas p.a. in the 1920 s as consultant to Queen Mary's Hospital for Children, Carshalton: Metropolitan Asylums Board Minutes, 1922, p. 220. Since 1933, the LCC had approved the appointment to its hospitals of certain medical and surgical specialists. However, it was reported in 1939 that "very little further progress in this direction has ... been possible, owing to the enormous amount of work involved in the reorganisation of the hospitals. Indeed, the only case in which action had been taken to implement the policy was the appointment of a surgeon specialist at Lambeth hospital." 'Extract of the Report of the Hospital and Medical Service Committee on LCC Hospital Division. Agenda for 14 March 1939', GLRO:PH/HOSP/4/28. At the meeting on fracture clinics held at County Hall, 16 June 1938, the appointment of full-time officers had been criticized on the grounds that "there would not be adequate competition between them and that this would ultimately be detrimental to their efficiency." GLRO:PH/HOSP/4/25, and see note 97 below.

${ }_{91}$ Voluntary Hospitals Committee for London, Organised Fracture Services for London: Report by Fracture Sub-Committee, June 1939, p. 6.

92 Platt had concluded his 1921 article op. cit., (note 20 above): "It is unnecessary to elaborate the obvious economic importance to industry in general of the efficient treatment of fractures. Those who are engaged actively in this work are aware of the fact that employers, insurance companies, and trade-unions are alive to the necessity for reform." The main American example of a company accident service was that organized in 1909 by William O'Neill Sherman (a member of the Fracture Committee of the American College of Surgeons) at the Carnegie Steel Corporation in Pittsburg: see T. L. Hazlett and W. W. Hummel, Industrial medicine in Western Pennsylvania 1850-1950, University of Pittsburg Press, 1957, pp. 73-75, 244-7. 
The motivating example was the work of H. E. Moore at the LMS Railway yards at Crewe. Begun on a small scale in the late 1920s at the suggestion of Gwynne Maitland (medical officer to the Cunard Steamship Company), Moore's rehabilitation of fracture cases became widely known in government and medical circles in the early 1930s. Personally threatened by the possible closure of the company hospital at Crewe, Moore became a strong advocate of the expert control and supervision of industrial injuries against what he saw as the incompetence of National Insurance general practitioners and hospital general surgeons. ${ }^{93}$ Although British orthopaedists as a professional body seeking entry into the teaching hospitals were not interested in industrial medicine as such, they found Moore's work useful in campaigning against the social and economic evils of the so-called "wastage" of industrial labour through medical incompetence. On the basis of Moore's work, it was argued that it was economically advantageous (for large self-insured companies at least) to have industrial injuries, and fractures in particular, treated by experts in order to avoid the unnecessary legal bother and expense of workmen's compensation claims and to avoid as well, purported malingering. ${ }^{94}$

Very largely, this was how the case was put in the appendix to the BMA's influential 'Report on fractures' of $1935 .{ }^{95}$ Since Moore and Maitland were among those who made up the committee that produced the report (along with Bristow and Hey Groves), the bias is hardly surprising. Yet beyond alerting employers to the issue of fractures, the pitch had little effect. In a context of high unemployment and cheap labour, few employers were seriously concerned about labour "wastage". Moreover, few employers were like Cunard Steamships or the LMS Railway in carrying their own insurance risks, and they therefore had as little incentive as the insurance companies to become directly involved with fracture treatment as a means to economy.

Ironically, the BMA's 'Report on fractures' made its deepest impact not among the managers of industry, but among organized labour (though, as we have seen, there were long-standing reasons why organized labour, and the TUC in particular, should have responded favourably). ${ }^{96}$ Ignoring the overtures of orthopaedists to industrialists, labour leaders took up the cause not only because of the serious effect of fractures on workers' wages and job retention, but also because here was an issue on the financial

\footnotetext{
${ }^{93}$ Moore, op. cit., note 69 above; idem, 'Observations on the after-care of industrial casualties', together with extracts from his Annual Reports of the Crewe Hospice, 1927-30, submitted to T. Carnwath, Ministry of Health, 22 December 1930, in GLRO:PH/HOSP/1/66; and see the obituary on Moore by Watson-Jones in $J$. Bone Jt Surg., 1952, 34B: 708. On the quiet but important role of Gwynne Maitland in the fracture movement, see his obituary, also by Watson-Jones, in ibid., 1949, 31B: 130-131.

94 Comparisons between average incapacity periods for fractures treated in "organized" fractureclinics and those "not treated in organized clinics" (but presumably in hospitals) were given in the BMA's 'Report on fractures', op. cit., note 17 above, pp. 54-55. Fractures of the femur, for example, were claimed to average thirty-seven weeks in an organized clinic as opposed to sixty weeks elsewhere. But see subsequent reneging and qualifying in R. Watson-Jones, 'Slow union of fractures', Br. J. Surg., 1943, 30: 260-275.

95 'Appendix: non-medical factors of prolonged disability', 'Report on fractures', op. cit note 17 above, pp. 60-62. Of the seventeen members of the BMA Fracture Committee, ten were members of the BOA; of the others, only H. S. Souttar, the Chairman, Henry Brackenbury, and Bishop Harman did not have a vested interest in the campaign for fracture clinics. Platt, who was not on the Committee, was then President of the BOA.

${ }_{96}$ See, for example, General Federation of Trade Unions, Report of Conference on Institutional Treatment of Fractures, 7 October 1936 at Onward Hall, Manchester, London, Co-op Printing Society, 1936.
} 


\section{Roger Cooter}

and social importance of which there was wide public agreement, ${ }^{97}$ it was a means to restate the accident-service rationale for a unified and "classless" hospital service, centrally co-ordinated and regionally administered and financed. Thus the TUC and Labour Party made fracture services a part of their political platform on health care and, jointly with the orthopaedists (officially through the BMA), presented a memorandum on rehabilitation and industrial injury to the government's InterDepartmental Committee in December $1937 .{ }^{98}$ Drafted and promoted by WatsonJones, the memorandum called for the deployment of experts in orthopaedic and traumatic surgery. It was subsequently presented to the (Hetherington) Royal Commission on Workmen's Compensation at its sittings of 1939-40, and, in general, its point of view and its emphasis on rehabilitation were taken up in the Beveridge Report and other pieces of war- and post-war legislation. ${ }^{99}$

This is not the place fully to enter into the social and political nature of the rapport between the TUC and Labour Party and the orthopaedic reformers, nor to dwell on the interesting resonances and ambiguities in the use of the term "rehabilitation". 100 Suffice to say here that the connexion with the TUC and Labour Party tempered the orthopaedists' pursuit of industrialists and encouraged them further along the road to state involvement in health care.

\section{EFFECTS AND MEANINGS}

If measured by the number of the hospital fracture clinics established before the Second World War, the orthopaedists' campaign for fracture services would have to be reckoned, at best, only a partial success. The government's (Delevigne) InterDepartmental Committee on the Rehabilitation of Persons Injured by Accidents, after announcing in their Interim report of 1937 that there were "many indications that a widespread movement for the establishment of fracture clinics has begun and is likely to make rapid headway", was forced to confess in its Final report of 1939 that "progress in the general application of them has not been as rapid as we hoped. The matter had been taken up in a number of places ... [but] the hope that a general movement had been started and would be carried through by the hospitals themselves, both voluntary and

\footnotetext{
${ }^{97}$ By the mid-1930s, opposition to segregated fracture treatment appears to have been minimal. The only opposition cited by the (admittedly partial) Delevigne Committee was that of certain general surgeons in Scotland who felt that the principle of a segregated service in a separate hospital department would entail "an inevitable loss of healthy rivalry between surgical members of the staff". No opposition from general practitioners is evident; indeed, the Delevigne Committee were confident that the "small number of fractures ... treated by general practitioners ... . may be expected to decrease in proportion to the spread of fracture schemes." Delevigne, Final Report, op. cit., note 58 above, pp. 32, 50.

${ }^{98}$ For the Joint TUC-BMA memorandum, see $B r$. med. J. suppl., 18 December 1937: 367-371; or 'Appendix D' to the Memorandum of Evidence by the TUC to the Royal Commission on Workmen's Compensation, op. cit., note 59 above, pp. 445-448; TUC General Council's Report to the Blackpool Congress, 1938, paragraphs 88-103; and 'Joint Committee of BMA and TUC (1936-9)', 3 vols., BMA archives. On the Committee itself, as viewed largely from the perspective of the TUC (and without reference to the fracture issue), see R. Earwicker, 'A study of the BMA-TUC Joint Committee on Medical Questions, 1935-1939’, J. Soc. Pol., 1979, 8: 335-356.

${ }_{99}$ See, in particular, [G. Tomlinson], Report of the Inter-Departmental Committee on the Rehabilitation and Resettlement of Disabled Persons, 1943, Cmd. 6415; and see Honigsbaum, op. cit., note 47 above ch. 24: 'The BMA-TUC alliance and the Beveridge Report'.

100 On the latter, see R. E. Matkin, 'Rehabilitation: an ambiguous term and unfulfilled ideal', Rehab. Lit., 1985, 46: 314-320.
} 
municipal individually or in co-operation, has not been realised." ${ }^{101}$ By 1939 only four out of twelve London teaching hospitals had fully developed fracture services, while 650 out of some 825 voluntary and municipal hospitals were still relying on "unorganized" general surgical routine for their fracture cases. Differences between hospitals, financial constraints, and the shortage of qualified fracture experts were among the many factors that held back the implementation and regional co-ordination of "ideal" fracture services.

More significant to the orthopaedic reformers than the findings of the Delevigne Committee, however, was the fact of its existence, and the fact that, despite its brief, it chose to concentrate exclusively on the issue of the organization of efficient fracture services. ${ }^{102}$ Like the BMA's 'Report on fractures', the Delevigne reports, by reiterating the orthopaedists' social, therapeutic, and economic rationales for efficient fracture treatment, legitimated the professional self-interests behind them. Not only did the Delevigne Committee justify the control of fractures in the hands of "fracture experts", 103 but also, by complying with the notion that the voluntary hospitals were the most appropriate place for fracture clinics, it granted to orthopaedists the status and authority they had been seeking, and the basis for the reproduction of that authority through access to undergraduate teaching. Further, by recommending "departure from ordinary practice in respect of ... remuneration" in the form of honoraria of between $£ 300$ and $£ 500$ per annum to the surgeon-in-charge of a fracture clinic, the Committee came close to accepting a salaried service for orthopaedists within the voluntary sector. ${ }^{104}$

But the Delevigne reports have an importance beyond that for orthopaedists. They stand, with measures such as the Cancer Act of 1939, as evidence of government commitment to an organized, statutory health service which included medical specialists and their work in voluntary hospitals. Previously, where government had been involved in health-care activities (such as tuberculosis schemes and those for maternity and child welfare), the concentration was on "public health" conceived largely in terms of preventive-cum-"personal health services". By the 1930s, however, the focus of development for central government and for many Medical Officers of Health lay with curative services, including the development of municipal hospitals, their staffing with consultants, and their relations with the voluntary hospitals. In these

${ }^{101}$ Delevigne, Interim Report, op. cit., note 56 above, p. 7; and Final Report, op. cit., note 58 above, p. 26. St Bartholomew's Hospital had a fracture service from 1927, but the in-patient treatment of fractures was shared by general surgeons, with only special cases being referred to the Orthopaedic Department. At St Thomas' and the Westminster hospitals a similar situation existed in the 1930s. A segregated fracture service adhering to the principles of continuity of treatment, unity of control under an orthopaedist, and after-care was established at the Manchester Royal Infirmary (under Platt) in 1936. See BMA 'Report on fractures', op. cit., note 17 above, p. $56 \mathrm{ff}$.

102 Delevigne Final Report, op. cit., note 58 above, pp. 4, 23-25, 121. The Committee took it as given that the principles of fracture organization as laid down in the BMA Report "were accepted by the Government Departments concerned".

103 Delevigne, careful always to avoid both controversy and dissent in his Committee, was well aware of "the difficulty which existed as to whether an orthopaedic surgeon or a general surgeon should undertake the treatment of fractures". At a meeting with Sir Frederic Menzies, 6 May 1938, he let it be known "that it was the intention of his committee to use the term 'fracture surgeon' only". GLRO:PH/HOSP/4/28.

104 Delevigne Interim Report, op. cit., note 56 above, p. 11 ; and see the editorial in Br. med. J., 1939, ii: 402-403. It was widely recognized that "honoraria" in this context was a euphemism for "salaries": see, for example, Medical Officer, 26 June 1937, 255. 
discussions, which lasted through the Second World War, "medical rationalizers" played a key role-some of whom were Medical Officers of Health, some of whom were medical academics, and several of the most active of whom were specialists who needed hospital rationalization to develop generally available services. Among the specialists (as Honigsbaum has observed) orthopaedists were conspicuous-an obvious and important example being Harry Platt, who was active on Manchester's Joint Hospitals Advisory Board before becoming involved, nationally, with the Nuffield Provincial Hospitals Trust. That one of the first acts of the Joint Board in Manchester was the implementation of a regional fracture scheme, and that the first report (1939) of the Nuffield Trust outlined a scheme for a unified accident service ${ }^{105}$ is not simply an indication of the influence and interests of Platt, however. Platt's career was typical of several contemporary would-be specialists who similarly moved through the small voluntary hospitals to regional hospital centres to involvement with the organization of the National Health Service. ${ }^{106}$ In considering these parallel careers, what emerges clearly is not the particular, but the general importance of the orthopaedic case. Accidents, like cancer, were on a new frontier of "public health" - a frontier that was part and parcel of the argument for rationalization and specialization. From this wider perspective, the reports by the BMA and the Delevigne committees appear less as orthopaedic reports in government dress, than as particular instances of the reformist stratagems of consultant specialists.

Clearly, then, the campaign for segregated hospital fracture services under orthopaedic specialists was about much more than meeting the need in interwar Britain for improved fracture treatment. As an emotive social issue into which could be drawn major interest groups from outside medicine ${ }^{107}$ the fracture issue provided one of the most visible and compelling of the arguments for technical expertise-an argument that could and was used to legitimate the reform of hospitals and the medical services as a whole. In this sense, the fracture movement did indeed "sanctify a cause". It is not surprising, therefore, that the investigation of the fracture movement illuminates various key aspects in the transformation to the hospital system of mid-twentiethcentury Britain.

\section{ACKNOWLEDGEMENTS}

This paper, and the research for the larger history of orthopaedics to which it refers, has been made possible by the generous support of the Wellcome Trust. Enormous personal debts are owing to the late Sir Harry Platt (1886-1986), who was interviewed repeatedly by me and my colleagues over the past few years and whose co-operation and support was unfailing. I am also grateful to Lady Watson-Jones and Norman Roberts for granting me interviews and hospitality, and to the British Medical Association, the Royal College of Surgeons, and the British Orthopaedic Association for permitting me access to their archives. To John Pickstone, who arranged the larger project and invited me to undertake it, I am further indebted for much helpful advice.

105 For references and for discussion on both planning bodies, see Pickstone, op. cit., note 20 above, pp. 287ff, 301ff; and Neville M. Goodman, Wilson Jameson: architect of national health, London, Allen \& Unwin, 1970, p. 133 et passim.

106 Examples would include Geoffrey Jefferson (neurosurgery), John Morley (general and abdominal surgery and paediatrics), E. D. Telford (general surgery and orthopaedics), James Spence (paediatrics), and (although without the provincial background) E. Rock Carling (a London consultant with a special interest in radiology).

${ }_{107}$ The twenty-one members of the Delevigne Committee, for example, were drawn from the Ministries of Health, Labour, and Pensions, the Department of Health for Scotland, the BMA, the British Hospitals Association, the Accident Officers' Association, LMS Railways, Midland Colliers Owners' Mutual Indemnity, Durham Miners, National Union of Railwaymen, and the Scottish TUC General Council. BOA interests were represented by W. A. Cochrane and Ernest Hey Groves. 